Bangladesh J. Sci. Ind. Res. 42(4),397-416, 2007

\title{
Heavy Metal Concentration in Tannery Solid Wastes Used as Poultry Feed and The Ecotoxicological Consequences.
}

\author{
A. M. M. Maruf Hossain, ${ }^{\mathrm{a}}$ Tasbee Monir, ${ }^{\mathrm{a}}$ A. M. Rezwan - Ul - Haque, \\ M. Azizul Islam Kazi, ${ }^{\text {b* }}$ M. Shahidul Islam, ${ }^{\text {b }}$ and Syed Fazle Elahi ${ }^{a}$ \\ ${ }^{a}$ Department of Soil, Water and Environment, University of Dhaka and \\ ${ }^{b}$ Analytical Research Division, BCSIR Laboratories, Dhaka, Bangladesh
}

\begin{abstract}
In Bangladesh, the tannery solid wastes are converted to protein-concentrate to be used as poultry feed, fish feed, and in production of organic fertilizers. Over the last several years it is a common phenomenon in the largest tanning area of the country, the Hazaribagh tannery area at the south-east part of Dhaka city. One of the major concerns of these activities is the heavy metals, especially chromium, used in the tanning processes. A total of 18 samples were collected to study the heavy metal status of protein-concentrate production in the tanning area at various stages from the source to the final product, and to compare this with the imported ones. The various types of solid waste processing for protein-concentrate production were covered in sampling, and along with the heavy metal status these processes were studied comprehensively. The maximum chromium content of the solid waste was found to be 3.2 $\%$. The final products sampled at two different places contained as high as $2.49 \%$ and $1.94 \%$ chromium. Cadmium, lead, arsenic, and mercury contents of all samples were also determined. The detected maximum and minimum concentrations of these elements were found to be: $3.888 \mathrm{ppm}$ and $0.991 \mathrm{ppm}$ for cadmium, $30.114 \mathrm{ppm}$ and $7.577 \mathrm{ppm}$ for lead, $2.212 \mathrm{ppm}$ and $0.099 \mathrm{ppm}$ for arsenic, and $13.916 \mathrm{ppm}$ and 0.166 ppm for mercury.
\end{abstract}

Key words : Heavy metal, Food chain, Ecotoxicology, poultry feed.

\section{Introduction}

Dhaka, a megacity of Bangladesh, is one of the most densely populated cities in the world. In the south-west part of the city, there is a tannery area consisting of about 185 tanning industries occupying 25 hectares of land at Hazaribagh. Leather, a traditional

* Corresponding author 
export item in Bangladesh, enjoys a good reputation worldwide for their quality. This sector plays a significant role in the economy of Bangladesh in terms of its contribution to export and domestic market. The tanning industries of Hazaribagh are processing some 220 metric tons of hide a day with an associated release of 600 - $1000 \mathrm{Kg}$ of solid waste resulting from production of each ton processed hide (Zahid, et al., 2004). These wastes are converted to protein-concentrate to be used as poultry feed, fish feed, and in production of organic fertilizers with some treatment. One of the major concerns of these activities is the heavy metals, especially chromium, used in the tanning processes.

The solid wastes are sliced cut pieces of hides produced at the end of some tanning processes. Generally the solid wastes are of greenish-blue colored. At the various sampling sites at Hazaribagh, two types of solid wastes were found, which could be distinguished by the color due to variations in the tanning processes undergone by hides. One of the two types was strong greenish-blue colored while the other was faded greenishblue colored. During the tanning processes chemicals get adsorbed as well as absorbed into the hides.

The solid wastes, being sliced cut-pieces of hides, are proteinaceous. These wastes are converted to protein-concentrate to be used into poultry feed, fish feed, and in production of bio-fertilizers without any appropriate treatment. At present, several large and many small mills are converting the solid wastes into protein-concentrate for mixing into poultry feed. Each large mill produces 200-250 tons of protein-concentrate per day.

In the most tannery industries at Hazaribagh, the stages of processing involve chrome tanning which uses chromium salts in large amounts. For the tanning property the chrome compound must have hydroxyl group in the complex directly attached to the chromium atom. That is why, the initial goal of chrome tanning is to get basic chrome compound from dichromate salts of chromium shown in the following reactions.

$\mathrm{Na}_{2} \mathrm{Cr}_{2} \mathrm{O}_{7}+\mathrm{H}_{2} \mathrm{SO}_{4}=\mathrm{Na}_{2} \mathrm{SO}_{4}+\mathrm{H}_{2} \mathrm{Cr}_{2} \mathrm{O}_{7}$

$\mathrm{H}_{2} \mathrm{Cr}_{2} \mathrm{O}_{7}+5 \mathrm{H}_{2} \mathrm{SO}_{4}+6 \mathrm{Na}_{2} \mathrm{~S}_{2} \mathrm{O}_{3}=$ $2 \mathrm{Cr}(\mathrm{OH}) \mathrm{SO}_{4}+3 \mathrm{Na}_{2} \mathrm{SO}_{4}+3 \mathrm{Na}_{2} \mathrm{~S}_{4} \mathrm{O}_{6}+5 \mathrm{H}_{2} \mathrm{O}$

In modern method pre-prepared basic chromium compounds, most commonly basic chromium sulfate (BCS), instead of dichromate salts is used. So, whether basic chromium sulfate or dichromate compounds are used, the concern is with basic chromium sulfate. Apart from this a few of the industries use alum tanning and the associated solid wastes released from these should contain less chromium but much more aluminum. In that case the toxicological and 
carcinogenic effects of aluminum should be the major concern.

Large amounts of chrome powder and chrome liqueur are used during tanning process. Some $47 \%$ corium collagen and $85 \%$ chemicals enter the waste streams as effluent (UNIDO, 2000). This means that some $53 \%$ of the corium collagen and $15 \%$ of the chemicals used are retained in the leather.

There are many hazards associated with the chemicals used in the tanning processes. But the hazards can come out in two ways. One is directly by external exposure or inhalation of the chemicals used and retained, or through the waters of canals and rivers after mixing with the released effluents. Substantial work has been done to study this. But the other way, which is probably not yet studied, is the entering of harmful chemicals into the food chain through the use of solid wastes as feed staff. This is a recent phenomenon happening at large extent for the last several years. That is why, at the very first, the protein-concentrate production processes practiced at Hazaribagh were surveyed and studied. Then the sampling was done to study the heavy metal status of protein-concentrate production at every detail from the source to the final product. These are covered at the first part of the research whereas in the second part the bioaccumulation of the heavy metals is planned to be studied through long experimentation. The concern of this research is the heavy metals, especially chromium, present in the chemicals used during tanning.

\section{Materials and Methods}

\section{Study area}

Hazaribagh Thana (Dhaka district) with an area of 3.58 square kilometer is surrounded by Mohammadpur thana on the north, Kamrangirchar thana on the south, Dhanmondi and Lalbagh thanas on the east, Keraniganj upazila and Buriganga river on the west. It is situated on the south-west part of capital Dhaka. The study area is located between $23^{\mathrm{O}} 43.85^{\prime}$ to $23^{\mathrm{O}} 44.05^{\prime} \mathrm{N}$ latitude and $90^{\circ} 21.85^{\prime}$ to $90^{\circ} 22.15^{\prime}$ E longitude.

\section{Sampling}

A total of 18 samples were collected. The samples represent various stages of proteinconcentrate production from the solid waste to final product as well as imported protein concentrates for comparison with the local products. The samples were collected from three spots at Sonatengar of Hazaribagh (Sonatengar-I, Sonatengar-II, and Sonatengar-III), feed mill producing proteinconcentrate in Hazaribagh, and Nimtoli poultry market, Kotwali Thana, Dhaka. The sampling sites are described below. 


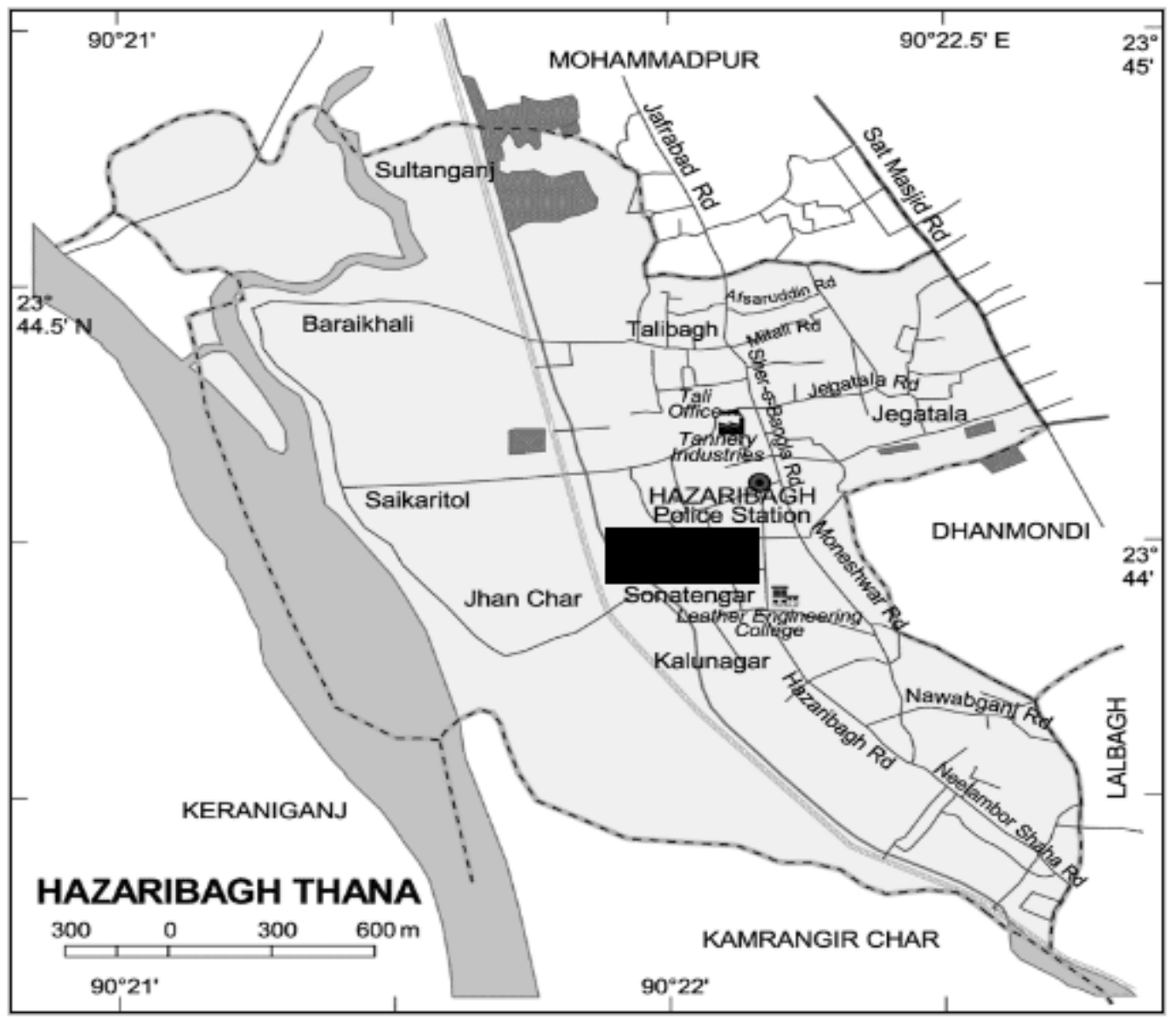

Fig. 1. Map of Hazaribagh Thana, Dhaka (blackened area of Sonatengar in the map represents the study area)

1. Three spots at Sonatengar, Hazaribagh, Dhaka. At the three spots the solid waste processing for the production of protein-concentrate were found different. That is why these three spots were selected for sampling.

- Sonatengar-I : At this spot, the two types of solid waste (visually different in color, the type I is greenish-blue colored and the type II is fade greenishblue colored) were boiled and sun-dried separately.

- Sonatengar-II: At this spot the type I solid waste was boiled and before drying, boiled animal gut was mixed with it. Then the mixture was sun-dried. 
- Sonatengar-III : At this spot both types (type I and II) of solid samples were mixed before boiling and then the boiled product was sun-dried.

2. Feed mill at Hazaribagh, and Nimtoli poultry market, Kotwali, Dhaka.

\section{Sample classification with identity}

The samples were classified into four classes as mentioned below. The solid waste type I was greenish-blue colored and the solid waste type II was faded greenish-blue colored.

V Class I (sample numbers 1 - 4) samples were sampled from Sonatengar-I.

- Sample 1 : Solid waste type I (greenishblue colored)

- Sample 2 : Solid waste type II (faded greenish-blue colored)

- Sample 3 : Solid waste type I + boiled + dried

- Sample 4 : Solid waste type II + boiled + dried

V Class II (sample numbers 5 - 10) samples were sampled from Sonatengar-II.

- Sample 5 : Solid waste type I (greenishblue colored)

- Sample 6 : Solid waste type I + boiled + dried
- Sample 7 : Boiled animal guts

- Sample 8 : Solid waste type I + boiled + mixed with boiled animal guts + dried

- Sample 9 : Boiled skin-cuts, ear, and tailcuts

- Sample 10 : Faded silver colored solid waste (probable waste from alum tanning)

V Class III (sample number 11 - 14) samples were sampled from Sonatengar-III.

- Sample 11 : Solid waste type I (greenishblue colored)

- Sample 12 : Solid waste type II (faded greenish-blue colored)

- Sample 13 : Mixture of solid waste type I and type II + boiled

- Sample 14 : Mixture of solid waste type I and type II + boiled + dried

V Class IV (sample number 15 - 18) samples were sampled both from Hazaribagh and Nimtoli poultry market, Dhaka.

- Sample 15 : Protein-concentrate sampled from feed mill at Hazaribagh, Dhaka

- Sample 16 : Protein-concentrate from "Asha Poultry”, Nimtoli (imported), Kotwali, Dhaka

- Sample 17 : Protein-concentrate from 
“Rupali Poultry”, Nimtoli (supplied from Hazaribagh)

- Sample 18 : Protein-concentrate from "Rupali Poultry”, Nimtoli (imported), Kotwali, Dhaka

\section{Sample pretreatment}

- The wet and moist samples were sundried to remove sensible moisture.

- Then the samples were oven-dried at $105^{\circ} \mathrm{C}$ to remove all moisture and thereby the moisture contents of the samples were determined. The samples were oven-dried unless the difference between two readings of weight was found negligible.

\section{Sample preparation method}

The samples were prepared by using $\mathrm{HNO}_{3}$ $\mathrm{HClO}_{4}$ digestion (Kebbekus and Mitra, 1998). Since the samples were of organic origin with a very high organic content, $\mathrm{HNO}_{3}-\mathrm{HClO}_{4}$ digestion was preferred over the more common $\mathrm{HNO}_{3}$ extraction for the determination of heavy metals. This strongly oxidizing digestion decomposes organics quickly and efficiently.

\section{Sample analysis}

For all the heavy metals analyses of the prepared samples were performed through atomic absorption spectrophotometry
(AAS). During the sample preparation for arsenic determination, hydrochloric acid (at least $11.6 \mathrm{ml}$ concentrated $\mathrm{HCl}$ for $100 \mathrm{ml}$ total sample) and KI (at least $1 \%$ ) were added. For the other heavy metals no special treatments were done. Hydride vapor generation technique was used in the determination of arsenic and mercury. Chromium, cadmium, lead, and arsenic determination were done in air-acetylene flame whereas mercury determination was done in cold vapor.

\section{Results and Discussion}

\section{Chromium}

The moisture content of the samples of class I were $27.13 \%, 27.24 \%, 12.68 \%$, and 8.08 $\%$ for sample number 1 to 4 , respectively. The class II samples contained $11.15 \%$, $11.27 \%, 52.50 \%, 13.37 \%, 6.16 \%$, and $51.36 \%$ moisture for sample numbers 5 to 10, respectively. The class III and class IV samples contained $51.30 \%$, $47.82 \%, 22.21$ $\%$, and $8.29 \%$ for sample numbers 11 to 14 , respectively and $10.04 \%, 6.17 \%, 10.66 \%$, and $6.49 \%$ for sample numbers 15 to 18 , respectively.

Results indicating chromium content of the samples in dry weight basis are presented in fig. II.

The level of the chief heavy metal of interest in this research, chromium, is very high. 

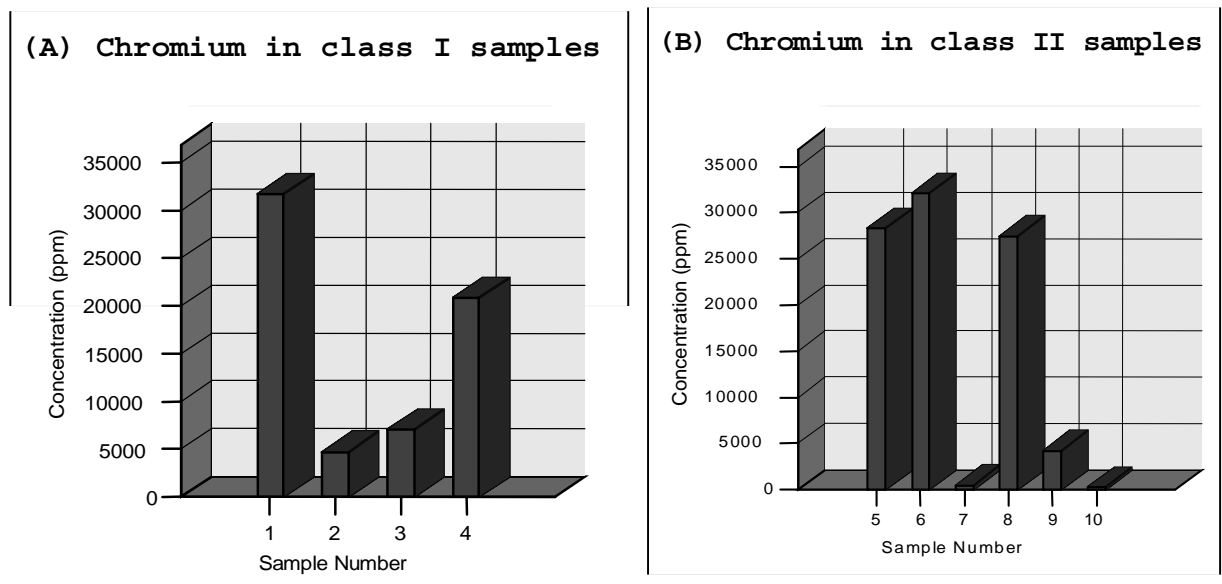

(C) Chromium in class III samples

(D) Chromium in class IV samples
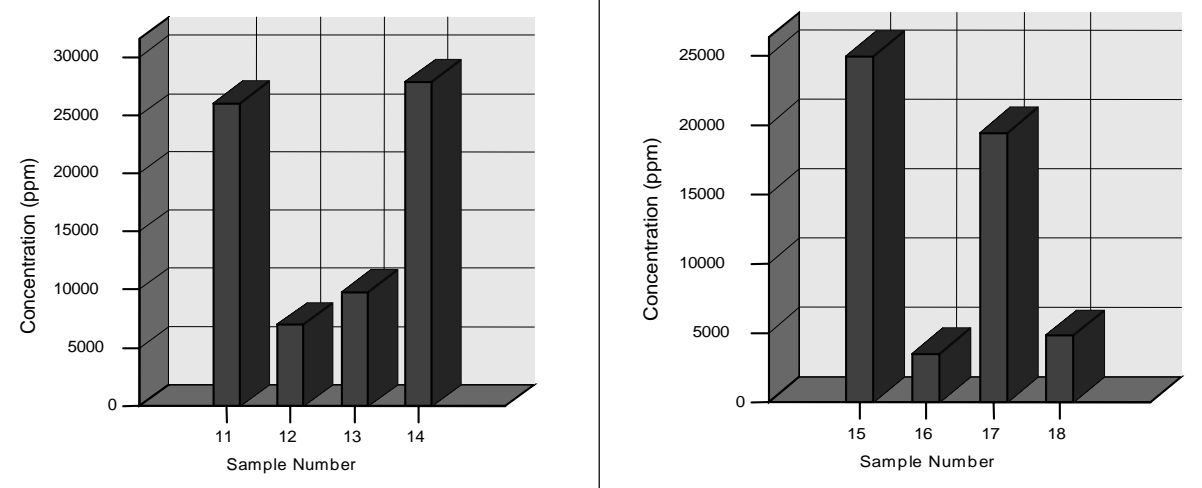

Fig. 2. Chromium concentration in the samples. (A) Chromium in class I samples; (B) Chromium in class II samples; (C) Chromium in class III samples; (D) Chromium in class IV samples

Maximum chromium content of solid waste was found to be $3.2037 \%$. Data analysis shows that boiling and drying treatments brought no significant change in chromium levels in samples collected from the three different spots of sampling. In one case the concentration becomes higher while in other it is lowered. So it can be concluded that the source of solid waste for any specific spot was not fixed rather the solid wastes were collected from various tanning units of Hazaribagh. That is why, for the chromium level what is at the dumping of solid waste is not the same which is being boiled and also which is sun-dried after boiling. As the sampling was done at a time from the dumping 
of solid waste and the waste after boiling and drying treatments, no regular change in chromium level among the treatments could be found. Since no extract is eliminated from the boiling of solid wastes, it can be said that, no change in chromium level other than change in oxidation state is expected during the process of boiling with water.

Protein-concentrate sampled from feed mill at Hazaribagh (sample 15) produced chromium concentration of $2.4901 \%$ as element. The rest of the three samples of protein-concentrates were sampled from Nimtoli poultry market, Dhaka - 2 from 'Rupali Poultry' and 1 from 'Asha Poultry'. One of the protein from 'Rupali Poultry' (sample 17) contained $1.939 \%$ chromium. It was supplied from Hazaribagh. The other protein from Rupali (sample 18) and the protein from 'Asha Poultry' (sample 16) were imported proteins and contained lower chromium concentration (0.4795 \%, and $0.3479 \%$ respectively) in comparison to the local two proteins.

Chromium as heavy metal has no adverse effect. The trivalent form of chromium is considered as essential for normal carbohydrate and lipid metabolism (NRC, 1980). Little toxic effect is attributed to trivalent chromium when present in large concentrations. However, $\mathrm{Cr}$ (III) is ubiquitous in nature, occurring in air, water, soil, and biological materials.
The most commonly used chromium compound in the tanneries of Hazaribagh is basic chromium sulfate (BCS). Chromium sulfate is initially trivalent but gets oxidized if left open to atmosphere to hexavalent chromium, which is carcinogenic. The most important toxic effects, after contact, inhalation, or ingestion of hexavalent chromium compounds include: dermatitis, allergic and eczematous skin reactions, skin and mucous ulcerations, perforation of the nasal septum, allergic asthmatic reactions, bronchial carcinomas, gastro-enteritis, hepatocellular deficiency, and renal oligo-anuric deficiency (Baruthio, 1992). Ingestion of $\mathrm{Cr}$ (VI) at just 30 to $40 \mathrm{mg} / \mathrm{Kg}$ of $\mathrm{BW} / \mathrm{d}$ dose even has induced toxicosis in dairy calves (European Commission, 2003).

In the carcinogenic behavior of chromium, chromate $\left(\mathrm{CrO}_{4}{ }^{2-}\right)$ (which is a strong oxidizing agent) is reduced intracellularly to $\mathrm{Cr}^{5+}$ inside biological system and reacts with nucleic acids and other cell components to produce mutagenic and carcinogenic effects on biological systems (Clark, 1994; McLean and Beveridge, 2001).

But Cohen and Costa (2000) mentioned about derived trivalent form of chromium to be ultimately responsible for the carcinogenic effect. The Cr (VI) ion is readily taken up into eukaryotic cells by anion-carrying proteins, after which it is reduced to $\mathrm{Cr}$ (III) 
by a number of cytoplasmic reducing agents. During this reduction process, unstable intermediates of $\mathrm{Cr}$ (V) and $\mathrm{Cr}$ (IV) are formed by interacting with reduced glutathione. The final cellular form of chromium, Cr (III), becomes trapped intracellularly because it has low cell membrane permeability. This shift from Cr (VI) to Cr (III) allows a concentration gradient to be established such that a continual influx of $\mathrm{Cr}$ (VI) ions raises intracellular chromium levels until lethal burdens are achieved. While both valence states of chromium are able to interact with DNA, Cr (III) ions are responsible for decreasing the fidelity of DNA replication. In addition, both $\mathrm{Cr}$ (III) and $\mathrm{Cr}$ (VI) exhibit a clastogenic potency; however, $\mathrm{Cr}$ (VI) possesses the greater activity and is also a powerful mutagen in many prokaryotic and eukaryotic cell systems. These properties of Cr (VI) support the claim that hexavalent compounds are likely to be active carcinogens, although it is more likely that the ultimate species responsible for the carcinogenic/mutagenic effects observed in vivo is the intracellularly derived trivalent form.

\section{Cadmium and Lead}

Dry weight basis cadmium and lead levels of the analyzed samples are presented in figure 3 and figure 4, respectively.

Cadmium was found in all the samples of Class I, II, and III (the maximum and mini- mum values for the samples are $3.279 \mathrm{ppm}$ and $0.991 \mathrm{ppm}$ ); but finally in the produced protein-concentrate it was diluted because of addition of other substances in the final protein and was not detectable at ppm level. But the two samples of imported protein collected from local market (Nimtoli, Kotwali, Dhaka) showed presence of cadmium (3.888 ppm in sample number 16, and $2.041 \mathrm{ppm}$ in sample number 18). So out of the four protein-concentrates sampled, the two local proteins (sample numbers 15 and 17) contained no cadmium at ppm level and the two imported samples showed presence of cadmium.

Lead was detected in only one sample at ppm level (sample 14 contained 29.716 ppm) out of 14 samples from class I, II, and III. From the two local protein-concentrate one showed detectable lead at ppm level (sample 17 contained 23.517 ppm) but both of the imported proteins showed lead at 7.577 ppm for sample 16, and 30.114 ppm for sample 18.

Cadmium and lead are nonessential nutrients that are of direct concern to human and livestock health and may accumulate in the body, particularly in the kidney, liver, and to a lesser extent in the muscle (Li et al., 2005). Most of us ingest heavy metals (i.e., lead and cadmium) via food in our daily diets, although the quantity of heavy metals varies 

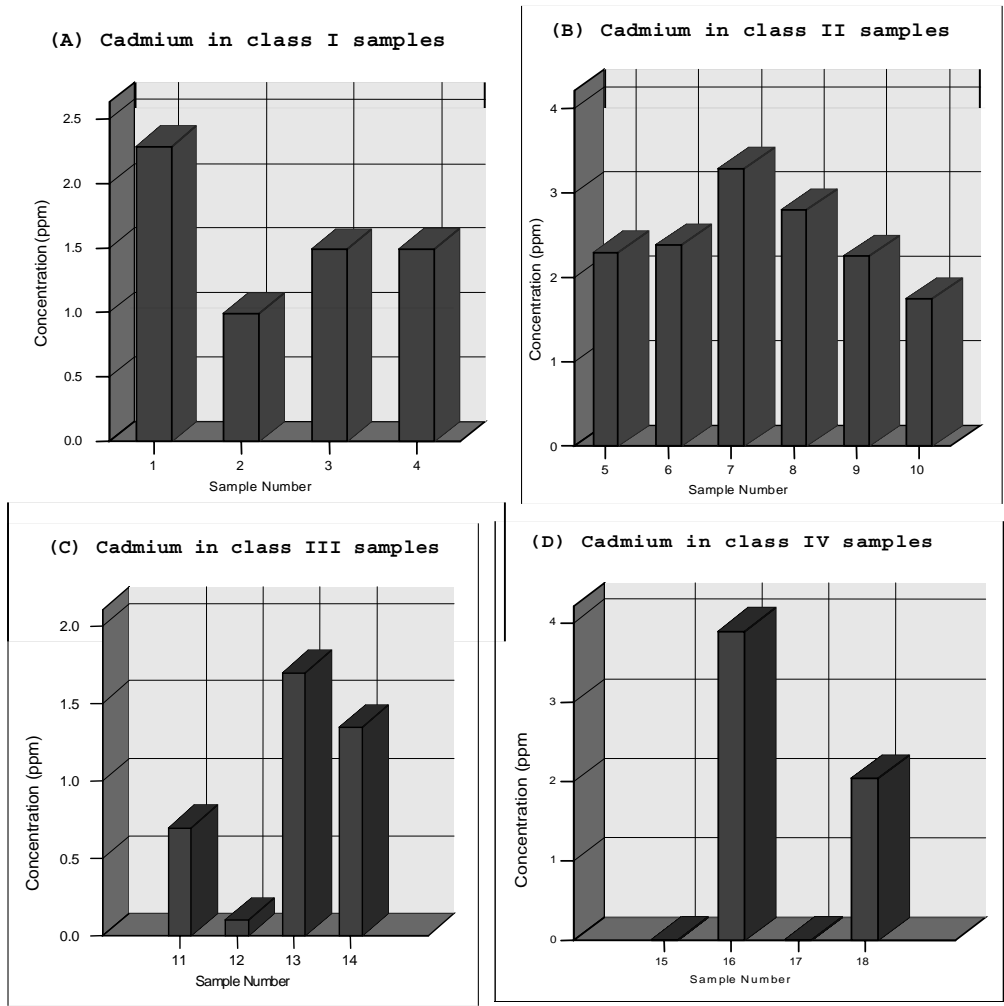

Fig. 3. Cadmium concentration in the samples. (A) Cadmium in class I samples; (B) Cadmium in class II samples; (C) Cadmium in class III samples; (D) Cadmium in class IV samples.
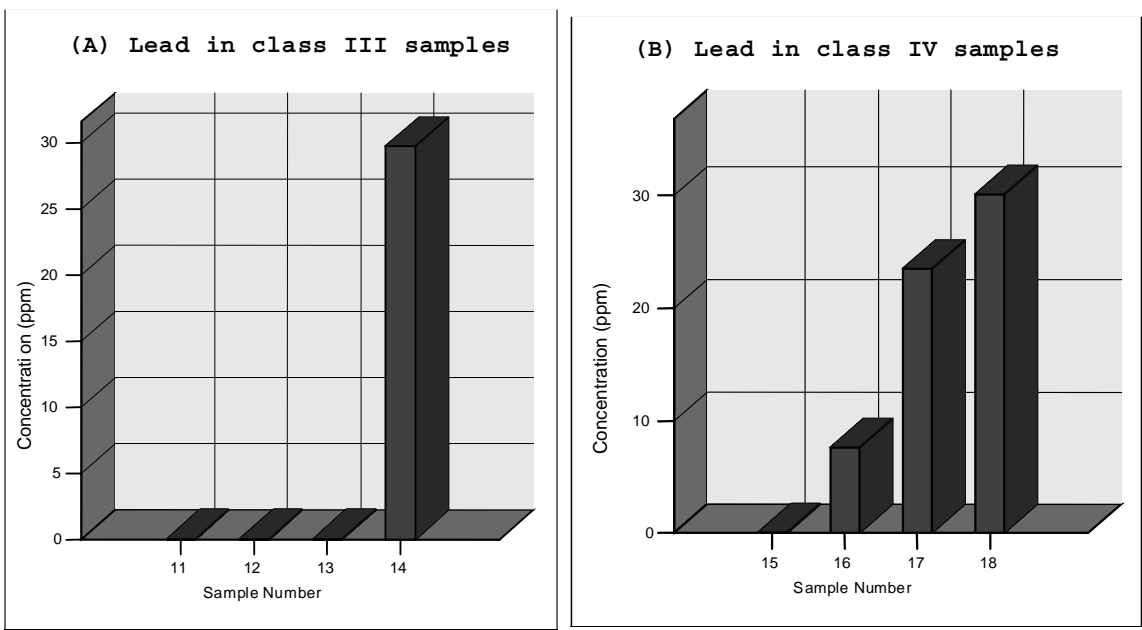

Fig. 4. Lead concentration in the samples. (A) Lead in class III samples; (B) Lead in class IV samples. There was no detection at ppm level for the sample classes I and II. 
from place to place, depending on dietary habits (Louekari and Salminen, 1986) and levels of environmental pollution (Harrison and Laxen, 1984). Works suggested susceptibility of dairy cattle to the accumulation of cadmium and lead (Alonso et al., 2003). Hassan et al. (1998) conducted experiments with multiple heavy metals including cadmium, copper, lead, and mercury added to water at high and low concentrations for 7 weeks.

They reported stable adverse effects on some immune parameters of chicks. The main sites of accumulation for lead and copper were bone and liver, respectively, while cadmium and mercury were found in kidney. The residue found in muscle was lower than that in other tissues.

Accumulation of cadmium has been observed in the ovaries and uteri of dairy cows (Smith, 1986) that may have an impact on reproduction. Heavy metals have an inherent affinity toward reproductive organs (Meluzzi et al., 1996). Earlier this century, the majority of poisoning cases in animals resulted from lead consumption (NRC, 1980). Consumption of lead-containing paint chips also resulted in numerous cases of toxicosis in humans and animals (Henry and Miles, 2001). Lead accumulates in bones and appears to be relatively immobile. Birds absorb approximately $10 \%$ of dietary lead (NRC, 1980).
The effects of acute cadmium poisoning in humans are very serious. Among then are high blood pressure, kidney damage, destruction of testicular tissue, and destruction of red blood cells. It is believed that much of the physiological action of cadmium arises from its chemical similarity to zinc. Specifically, cadmium may replace zinc in some enzymes, thereby altering the stereostructure of the enzyme and impairing its catalytic activity, and disease symptoms are ultimately resulted (Manahan, 1997). Despite the evidence dealing with the carcinogenic potency of cadmium in experimental animals, its carcinogenicity in humans is not well defined (Costa, 2000). However, 'International Agency for Research on Cancer' has classified cadmium and its compounds as a Group I human carcinogen (IARC, 1993).

Lead compounds may have a variety of targets within the nervous system causing neurotoxicity (Bondy, 1988). Lead has multiple serious health effects. Acute lead poisoning in humans causes severe dysfunction in the kidneys, reproductive system, liver, and the brain and central nervous system; causing sickness or death. Lead poisoning from environmental exposure is thought to have caused mental retardation in many children. Mild lead poisoning causes anemia. The victims may have headaches and sore muscles and may feel generally fatigued and irritable (Manahan, 1997). 


\section{Arsenic and Mercury}

Dry weight basis arsenic and mercury contents of the samples are presented in figure 5 and figure 6, respectively.
Arsenic was detected in three samples out of 14 samples from class I, II, and III (maximum $0.373 \mathrm{ppm}$ and minimum $0.099 \mathrm{ppm}$ ). Out of the four protein-concentrates the two local proteins did not contain arsenic at ppb

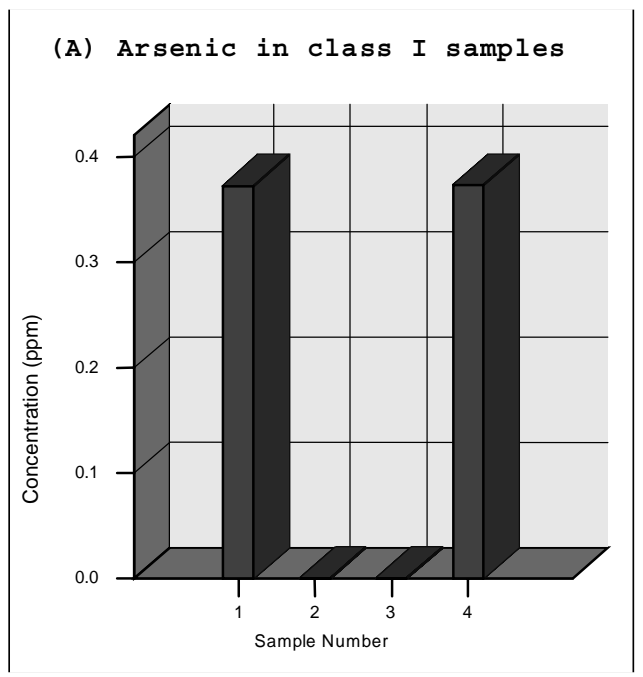

(B) Arsenic in class II samples
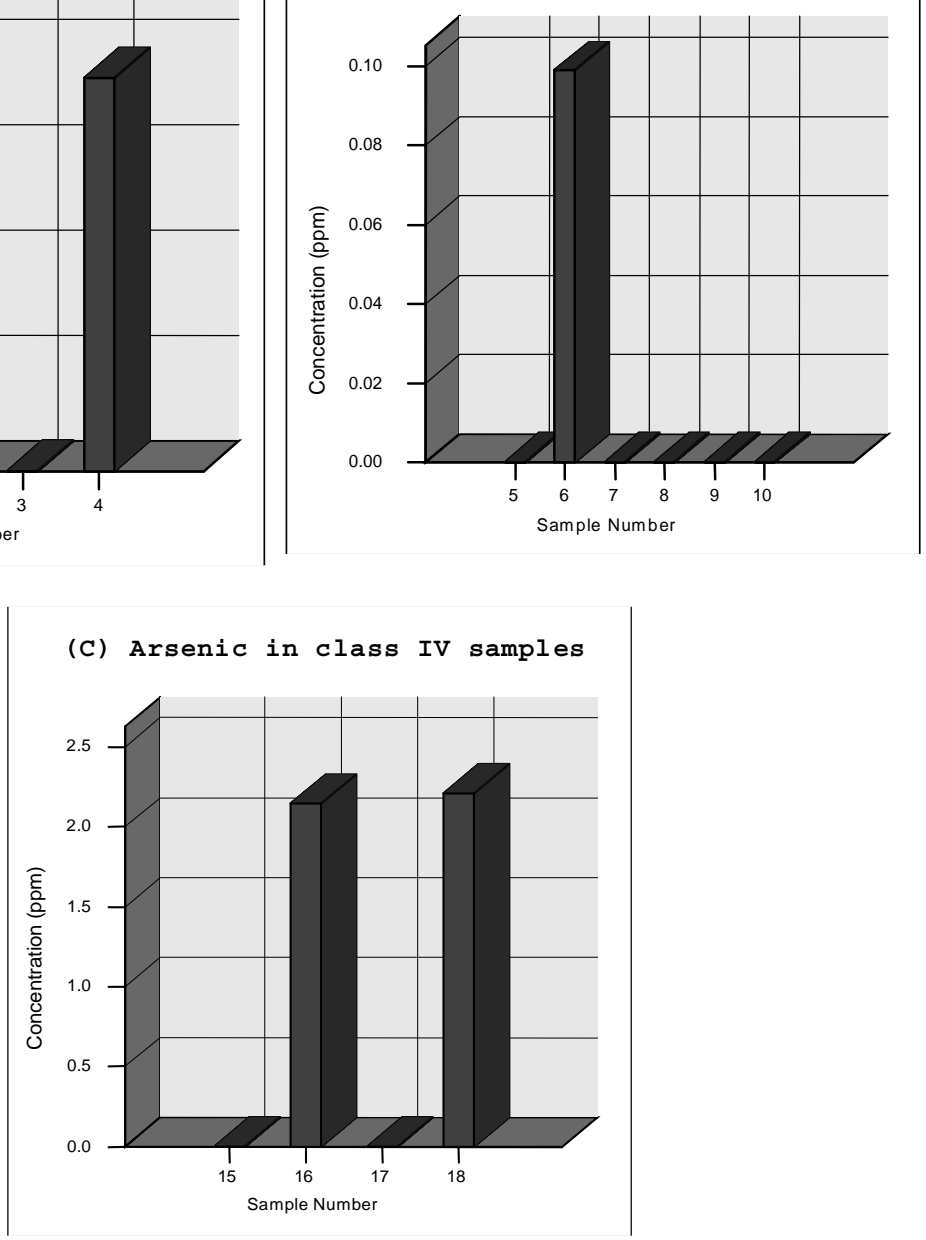

Fig. 5. Arsenic concentration in the samples. (A) Arsenic in class I samples; (B) Arsenic in class II samples; (C) Arsenic in class IV samples. There was no detection at ppb level for the sample class III. 


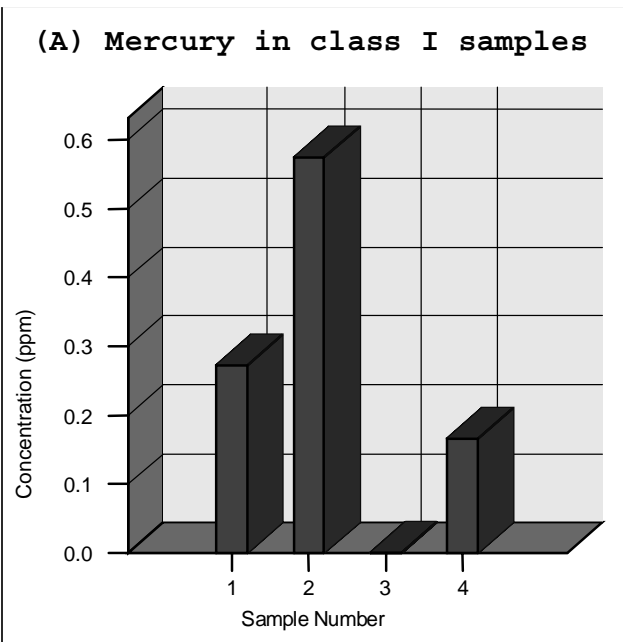

(B) Mercury in class II samples

(C) Mercury in class III samples
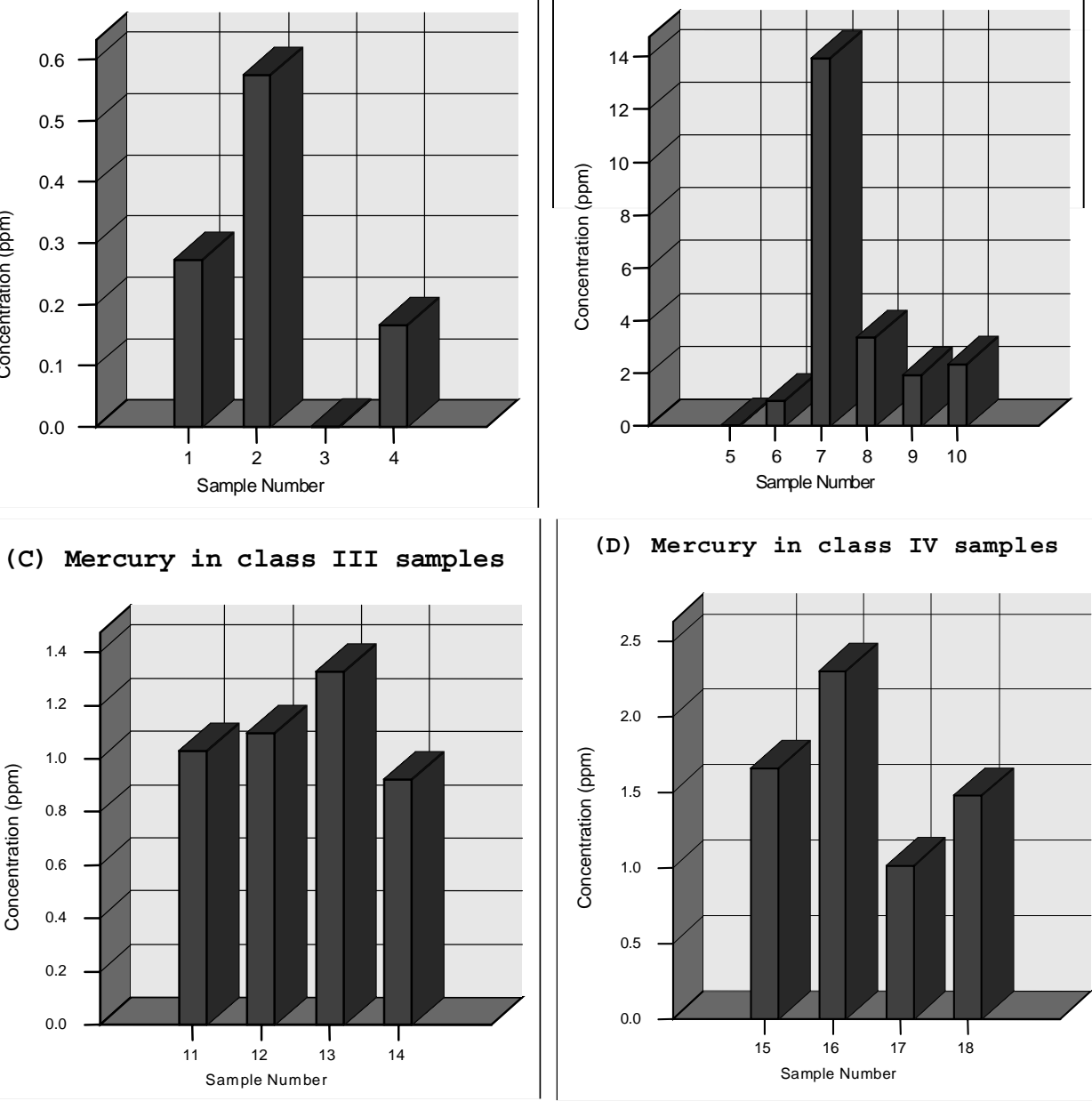

(D) Mercury in class IV samples

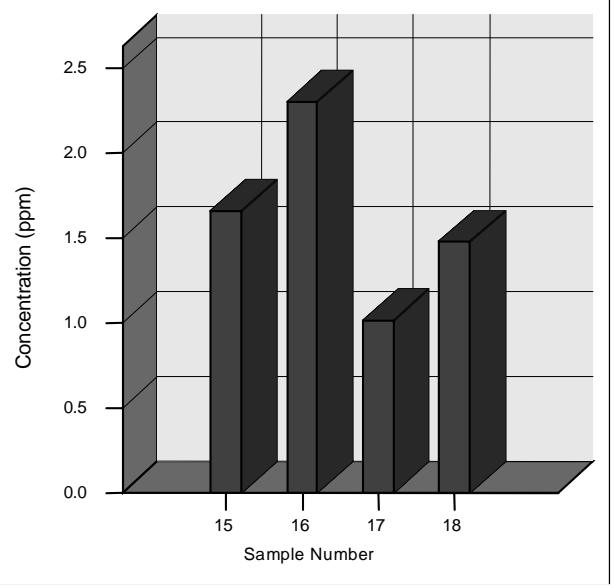

Fig. 6. Mercury concentration in the samples. (A) Mercury in class I samples; (B) Mercury in class II samples; (C) Mercury in class III samples; (D) Mercury in class IV samples

level while the two imported proteins contained arsenic (2.146 ppm for sample 16, and $2.212 \mathrm{ppm}$ for sample 18).

Mercury was present in all of the samples except sample 3 and 5 though measured at the ppb level. Except sample 7 (boiled animal guts) mercury concentration ranged from $0.166 \mathrm{ppm}$ to $3.337 \mathrm{ppm}$. Sample 7 contained maximum mercury (13.916 ppm). The local proteins contained 1.658 and 1.014 ppm (samples 15 and 17) while the imported 
proteins contained 2.301 and $1.475 \mathrm{ppm}$ (samples 16 and 18).

The As (III) is significantly more toxic than As (V) or the organic arsenicals, and the carcinogenicity and toxicity of the element mainly result from exposure to As (III). The ability of $\mathrm{As}^{3+}$ to inhibit ATP production suggests that organ function will cease rapidly, especially in the event of acute poisoning (Costa, 2000). Symptoms of acute exposure include severe inflammation of the gastrointestinal tract. These can be accompanied by secondary electrolyte disturbances, cardiac dysfunction, coma, and even death, as a result of cardiac failure (Flower et al., 1979). Other evident features include facial edema, anorexia, anemia, upper respiratory distress, skin lesions, neurotic signs, and hepatomegaly. Sensory loss in the peripheral nervous system is the most common neurological effect of acute arsenic exposure (Flower et al., 1979; Wesley and Kunis, 1981). Chronic exposure to arsenic via drinking water can frequently cause hyperkeratosis, white striae of the cutica, cardiovascular irregularities, myocardial ischemia, hypertension, liver dysfunction, hematological changes, blackfoot disease, Raynaud's syndrome, skin epithelima, and other cancers (Flower et al., 1979). The toxicity and carcinogenicity of arsenic is complicated by the different oxidation states of the metal. Although arsenic is a powerful clastogen, it is nonmutagenic in many mammalian cell systems. The carcinogenicity of arsenic in humans may not be dependent on interactions with any one specific region of DNA to yield mutations. It may, however, be related to the clastogenic activities which give rise to chromosomal rearrangements and breaks as well as deletions of important genes, namely tumor suppressor gene(s) (Costa, 2000).

Hassan et al. (1998) conducted experiments with multiple heavy metals including mercury added to water at high and low concentrations for 7 weeks and they found kidney as the main site of mercury accumulation. The toxicity of mercury was tragically illustrated in the Minamata Bay area of Japan during the period 1953-1960. A total of 111 cases of mercury poisoning and 43 deaths were reported among people who had consumed seafood from the bay that had been contaminated with mercury waste from a chemical plant that drained into Minamata Bay. Congenital defects were observed in 19 babies whose mothers had consumed seafood contaminated with mercury. The level of metal in the contaminated seafood was 5-20 ppm. The unexpectedly high concentrations of mercury found in fish tissues result from the formation of soluble monomethylmercury ion, $\mathrm{CH}_{3} \mathrm{Hg}^{+}$, and volatile dimethylmercury, $\left(\mathrm{CH}_{3}\right)_{2} \mathrm{Hg}$, by anaerobic bacteria in sediments. Mercury 
from these compounds becomes concentrated in fish lipid tissue by as much as a thousand-fold compared to the surrounding water. The methylating agent by which inorganic mercury is converted to methylmercury compounds is methylcobalamin, a vitamin $B_{12}$ analog (Manahan, 1997)

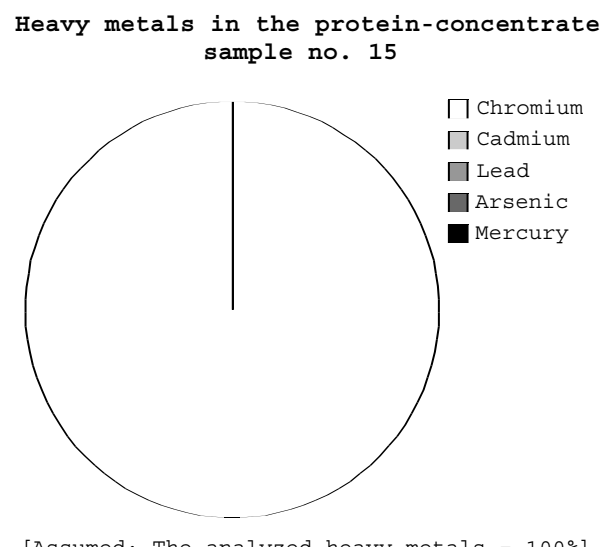

[Assumed: The analyzed heavy metals $=100 \%$ ]
$\mathrm{HgCl}_{2} \stackrel{\text { Methylcobalamin }}{\longrightarrow} \mathrm{CH}_{3} \mathrm{HgCl}+\mathrm{Cl}^{-}$

Mercury has both acute and chronic toxicity. Acute poisoning may cause gastrointestinal corrosion and irritation, such as vomiting, bloody diarrhea, and stomach pains. Shock and acute kidney dysfunction with uremia

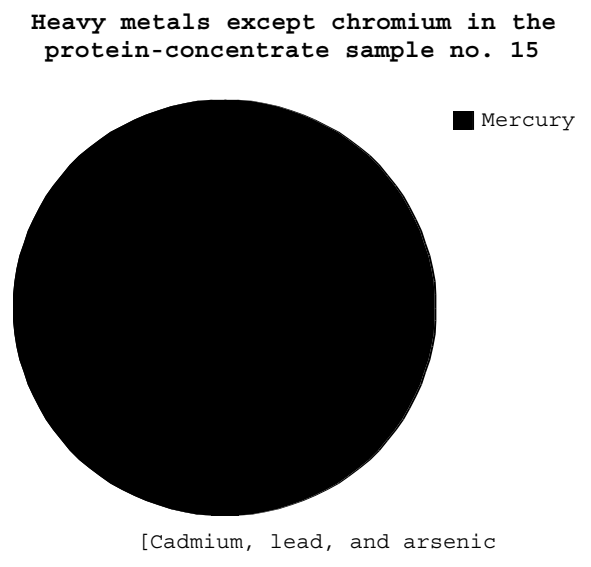

Fig. 7. Heavy metal concentration in protein-concentrate (sample 15). Left: All heavy metals analyzed; Right: Heavy metals except chromium

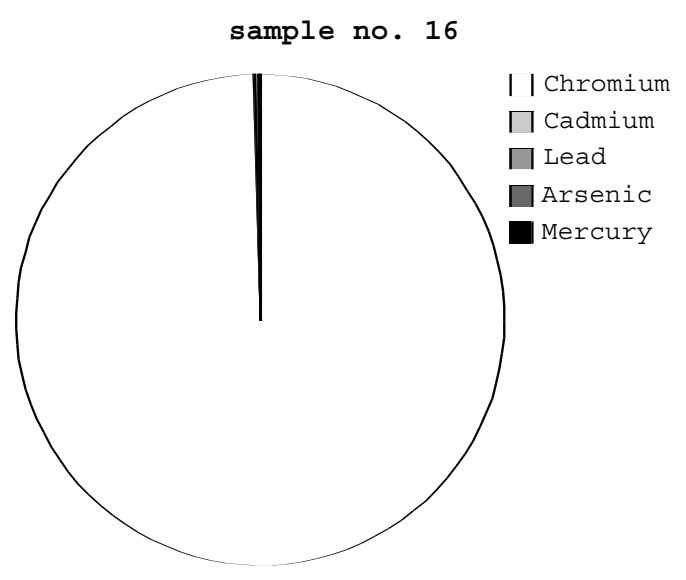

[Assumed: The analyzed heavy metals = $100 \%$ ]

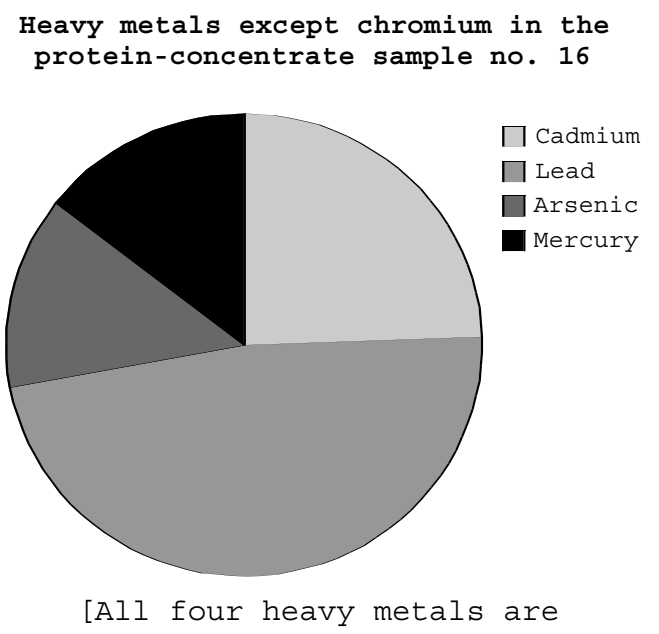

[All four heavy metals are

Fig. 8. Heavy metal concentration in protein-concentrate (sample 16). Left: All heavy metals analyzed; Right: Heavy metals except chromium 

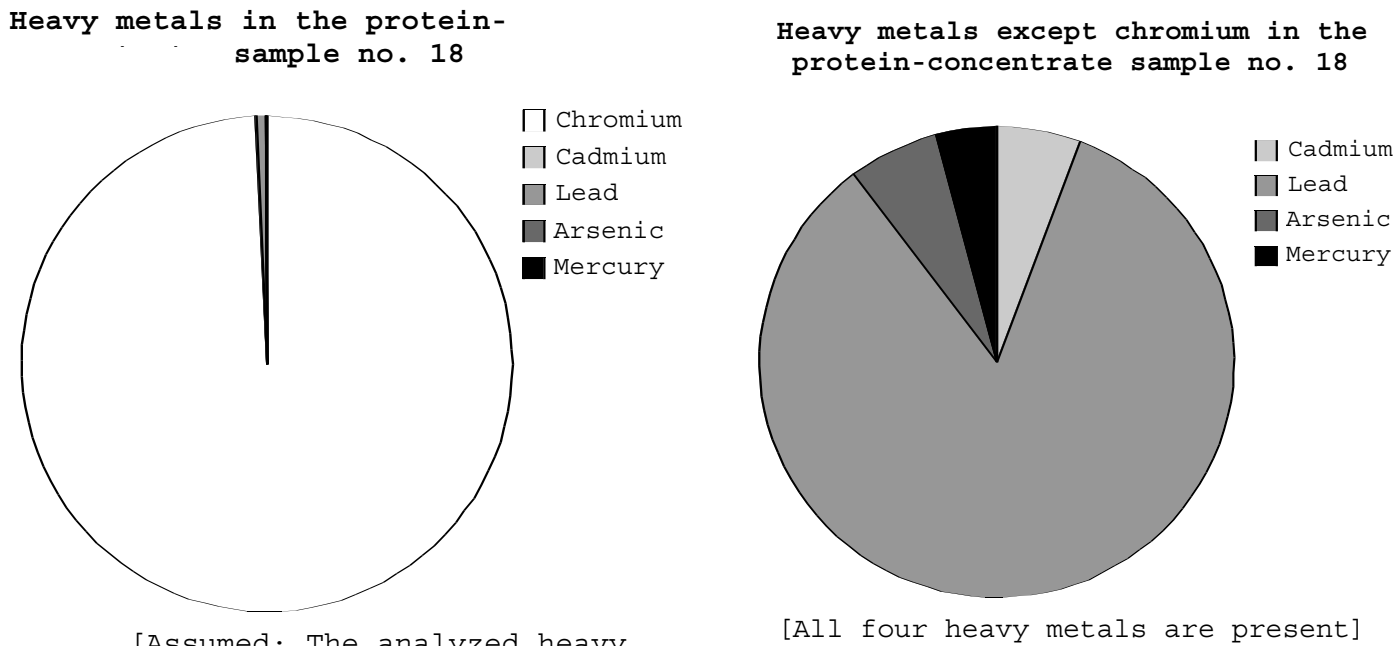

[Assumed: The analyzed heavy

[All four heavy metals are present]

Fig. 10. Heavy metal concentration in protein-concentrate (sample 18). Left: All heavy metals analyzed; Right: Heavy metals except chromium
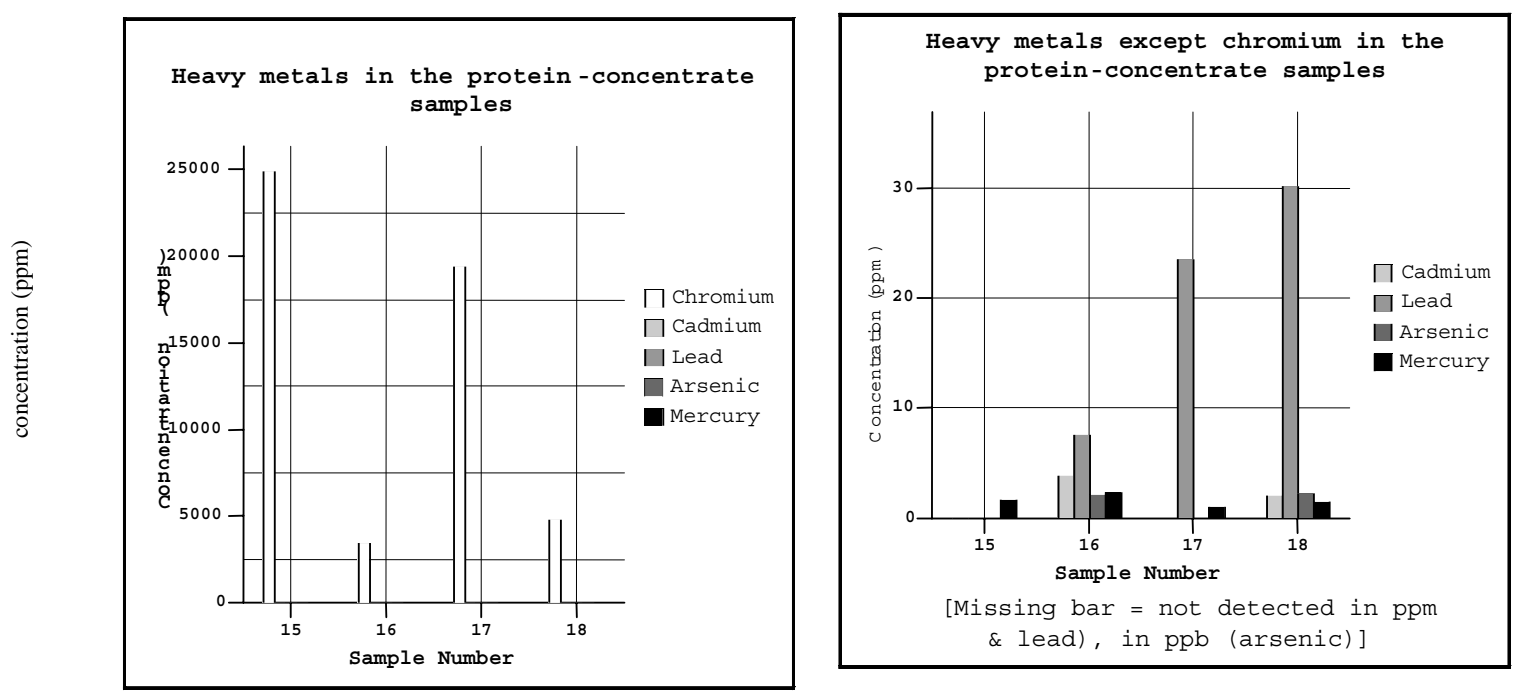

Fig. 11. Heavy metal concentration in the protein-concentrates. Left: All heavy metals analyzed; Right: Heavy metals except chromium

may ensue. The symptoms with chronic intoxication may involve the oral cavity, the peripheral and central nervous system, and the kidneys (Nielsen and Grandjean, 2000).
Comparison of heavy metals in the proteinconcentrate samples (sample class IV)

In the comparisons among the relative abundance of the heavy metals analyzed, it is 
readily evident that, the level of chromium in all four samples exceeds the rest of all heavy metals by far. Rather it is worth to say that the presence of other heavy metals in the protein-concentrates is negligible in comparison to the chromium level. In fact cadmium, lead, arsenic, and mercury produced highest values of $3.888,30.114,2.212$, and 2.301 ppm, respectively.

\section{Comparison of data with the standards}

In the "Poultry Feed Reference standards, February 2002”, prepared by Ministry of Fisheries and Livestock, the Govt. of the People's Republic of Bangladesh, there are maximum acceptable limits of heavy metals as contaminants only for drinking water that should be supplied to poultry. That standard was adopted from Carter and Sneed (1987) as referenced at the document. Again, that list only contains lead and arsenic from the heavy metals analyzed in this research, though arsenic was given only for the average levels found in the samples analyzed to prepare that standard. As that publication was from USA, the average level was zero so that no permissible standards could be required to fix. But in Bangladesh arsenic is one of the major concerns regarding drinking water. For lead, the maximum acceptable level was given $0.02 \mathrm{ppm}$ at the document.

There were also standards for some of the heavy metals for solid feed but that was as nutritional requirement (micro-nutrients), not as contaminant. But no heavy metal analyzed in this research is included at that list. Though chromium is a micro-nutrient for humans and many animals, it was not mentioned at the list which can be meant as; this element is not a micro-nutrient for poultry as per the document. But whatever it is, the macro-nutrients also have toxic even lethal effects when present in excessive amounts. In that perspective, chromium is present at very much excessive amount in the protein-concentrates especially at the local products sampled.

\section{Conclusion}

The target of the works done is actually protein-concentrates that are produced locally using tannery solid wastes. So, it is not the final feed that is supplied to the poultry directly. With this protein-concentrate the other feed stuffs are also mixed for the preparation of balanced diet. In that case two things come under consideration. The first one is the heavy metal level which is lowered in the final feed due to dilution. But it is not very significant where these protein-concentrates are used to prepare poultry diets. The other one is the feed staffs that are mixed with these proteins. The feed staffs may also contain the heavy metals. Though it can be said that this reverse thing can not make up the dilution of chromium in the 
final feed, but the concentrations of other heavy metals could even become higher depending on the sources of other feed staffs to be mixed. It is noticeable that the imported protein-concentrates also contain a high level of chromium, even in comparison with the other heavy metals present. Only in comparison to the local protein concentrates, it can be thought to be low.

To maintain the food chain safe from the entering of heavy metals and the subsequent ecotoxicological consequences, it is necessary to have definite standards for heavy metals for all possible pathways towards food chain. Then any phenomenon allowing heavy metals to enter into food chain beyond those limits can automatically be regarded as unsafe and will be directed for mitigation strategies. So, in the national guideline, the chapter for all potentially harmful heavy metals should be included in a definite way as contaminant showing maximum permissible limits, rather than nutritional requirements for the micro-nutrients.

\section{References}

Alonso, M.L., Montana, F.P. Miranda, M. Castillo, C. Hernandez, J. and Benedito, J.L. (2003). Cadmium and lead accumulation in cattle in NW Spain. Vet. Hum. Toxicol. 45 : 128-130.
Baruthio, F. (1992). Toxic effects of chromium and its compounds; Biol Trace Elem Res. 32 : 145-53.

Bondy, S.C. (1988). The neurotoxicity of organic and inorganic lead. In S. C. Bondy and K. R. Prasad (ed.) Metal Neurotoxicity. (CRC Press, Boca Raton, FL).

Carter, T.A., and Sneed, R.E. (1987). Drinking water quality for poultry. PS and T Guide No. 42, Extension Poultry Science, North Carolina State University, Raleigh, NC.

Clark, D.P. (1994). Chromate reductase activity of Enterobacter aerogenus is induced by nitrite. FEMS Microbiol. Lett. 122 : 233-238.

Cohen M.D. and Costa, M. (2000). Chromium. pp. 173-191. In Morton Lippmann (ed.) Environmental Toxicants: Human Exposures and Their Health Effects, 2/e. (John Wiley and Sons, Inc).

Costa, M. (2000). Trace elements: aluminum, arsenic, cadmium, and nickel. pp. 811-850. In Morton Lippmann (ed.) Environmental Toxicants: Human Exposures and Their Health Effects, 2/e. (John Wiley and Sons, Inc).

European Commission. (2003). Opinion of the Scientific Committee on Animal Nutrition on Undesirable Substances in Feed. 
European Commission, Health and Consumer Protection Directorate, Brussels, Belgium.

Flower, B., N. Ishinishi, K. Tsuchiya, and Vahter, M. (1979). Arsenic. pp. 1721-1723. In L. Friberg, G. F. Nordberg, and V. B. Vouk (ed.) Handbook on the Toxicology of Metals. (Elsevier North-Holland Biomedical Press, New York).

Harrison, R.H., and Laxen, D.P.H. (1984). Human Exposure to Lead and Its Effect in Lead Pollution, Causes and Control. pp 133-158. (Chapman and Hall, New York).

Hassan, A., Saleh, R. Sobih, M. Wilson S. and Reddy, P. (1998). Effect of some heavy metal pollutants on the performance and immune system of chicks. Poult. Sci. 77 (Suppl. 1) : 24.

Henry, P. R., and Miles, R.D. (2001). Heavy metals - vanadium in poultry. Cieência Animal Brasileira. 2(1) : 11-26.

IARC. (1993). Cadmium and Cadmium Compounds, vol. 58, pp. 119-237. IARC Monographs on the Evaluation of Carcinogenic Risks to Humans. (Lyon: International Agency for Research on Cancer).

Kebbekus, B.B., and Mitra, S. (1998). Environmental Chemical Analysis. (Blackie Academic and Professional, London).
Li, Y., McCory, D.F. Powell, J.M. Saam, H. and Jackson-Smith, D. (2005). J. Dairy Sci. 88 : 2911-2922.

Louekari, K., and Salminen, S. (1986). Intake of heavy metals from food in Finland, West Germany, and Japan. Food. Addit. Contam. 3 : 355-362.

Manahan, S.E. (1997). Environmental Science and Technology. (CRC Press/Lewis Publishers, Boca Raton, FL).

McLean, J. and Beveridge, T.J. (2001). Chromate reduction by a pseudomonad isolated from a site contaminated with chromated copper arsenate. Appl. Environ. Microbiol. 67 : 1076-1084.

Meluzzi, A. Simoncini, F. and Sirri F. (1996). Feeding hens diets supplemented with heavy metals (chromium, nickel, and lead). Arch fur Geflugelkunde. 60 : 119-125.

Ministry of Fisheries and Livestock, the Govt. of People's Republic of Bangladesh. (2002). Poultry Feed Reference Standards, Bangladesh.

Nielsen, J.B. and Grandjean, P. (2000). Mercury. pp. 563-575. In Morton Lippmann (ed.) Environmental Toxicants: Human Exposures and Their Health Effects, 2/e. (John Wiley and Sons, Inc). 
NRC. (1980). Mineral Tolerance of Domestic Animals. (National Academy Press, Washington, DC).

Smith, R.M. (1986). Effects of Long-term, Lowlevel Oral Cadmium on Performance, Blood Parameters, and Tissue and Milk Mineral Concentrations of Dairy Cattle through First Gestation and Subsequent Lactation. Ph.D. Diss., Pennsylvania State University, University Park.

UNIDO. (2000). Regional Programme for Pollution Control in the Tanning Industry in South-East Asia : Chrome Balance in Leather Processing. Prepared by J. Ludvik.
Wesley, G., and A. Kunis. (1981). Arsenic neuropathy. Illinois Med. J. 160 : 396-398.

Zahid, A., Balke, K.D., Hassan, M.Q., and Flegr, M. (2004) : Distribution of heavy metals in tannery effluent and their influence on sed iments of Hazaribagh leather processing zone, Dhaka. In M. Q. Hassan (ed.) Water Resources Management and Development in Dhaka City. (Gothe Institute Dhaka).

Received : July, 17, 2007;

Accepted : September, 12, 2007 